\title{
The role of infrastructure in improving human settlements
}

1 Priti Parikh FRSA, CEng, MICE, MPhil

Research Associate, Imperial College, Business School, Innovation and Entrepreneurship Group, London, UK
2. Himanshu Parikh FRSA, CEng, MICE

Director, Himanshu Parikh Consulting Engineers, Ahmedabad, Gujarat, India

3 Allan McRobie MSc, FIMA, CMath

Reader, Cambridge University, Cambridge, UK
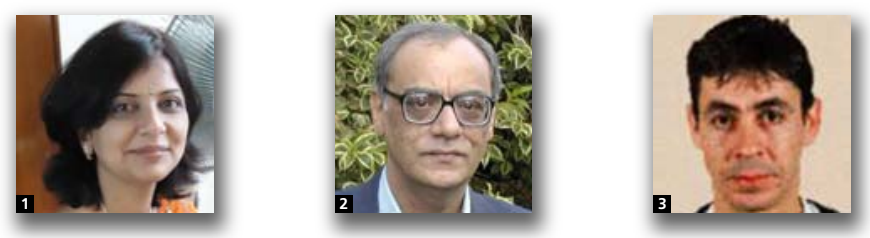

This paper considers how the provision of integrated household-level infrastructure - particularly water and environmental sanitation (including water supply, sewerage, roads, storm drainage and solid waste management) can play a leading role in improving the conditions in slum settlements. Around 700 socio-economic interviews were carried out in India and South Africa to investigate an innovative approach called slum networking, which sees the strong correlation between slum locations and drainage paths as an opportunity for improving the wider urban environment. This recognition allows resources to be mobilised locally, thereby removing the need for external aid funding. The evidence from the $\mathbf{7 0 0}$ families shows that communities perceive water and sanitation inputs to be their top priority and are willing to contribute to the costs. If slum upgrading is led with access to integrated water and environmental sanitation at household level with community contributions to the cost of infrastructure, then slum communities subsequently invest considerably greater sums in improved housing and education, with longer term contributions to poverty alleviation, improvements in health and literacy and an increase in disposable incomes.

\section{Introduction}

More than a billion people worldwide have no access to an improved water source, and $2 \cdot 5$ billion do not have access to improved sanitation (WB, 2004). Most of these people are possibly among those hardest to reach. In urban areas this sector predominantly comprises slum communities and lowincome communities. The WHO/UNICEF (2004) monitoring report also acknowledges that, without a sharp acceleration in the rate of progress, the world will miss the millennium development sanitation target by half a billion people.

This paper is based on an approach called slum networking, which has been used in Indore city in India for in situ slum upgrading. The upgrading is achieved through the provision of integrated household-level infrastructure in the form of water and environmental sanitation (roads, storm drainage and solid waste management) using community resources, thereby shifting emphasis from donor support to self-sufficiency. Through evidence-based research, using data from 700 interviews in India and South Africa, this paper investigates the impact of such household infrastructure provisions in slum communities.

\section{Slum networking}

Slum networking was first introduced in the city of Indore in India in 1987. This was a project funded by UKAid, which is the UK department for International Development. It was conceived and developed by the second author, Himanshu Parikh, a consultant engineer based in Ahmedabad (Diacon, 1997). Figure 1 shows the linkage between the slums and drainage paths/water bodies of the city. There are two possible reasons for this connection: ease of access to water and the ease of occupying land adjacent to rivers, which is usually government owned. These drainage paths constitute the most efficient paths for gravity-based infrastructure, so if water and environmental sanitation infrastructure are provided in all the slum pockets and then interconnected along the drainage paths, the main city can also gain cost-effective networks in 


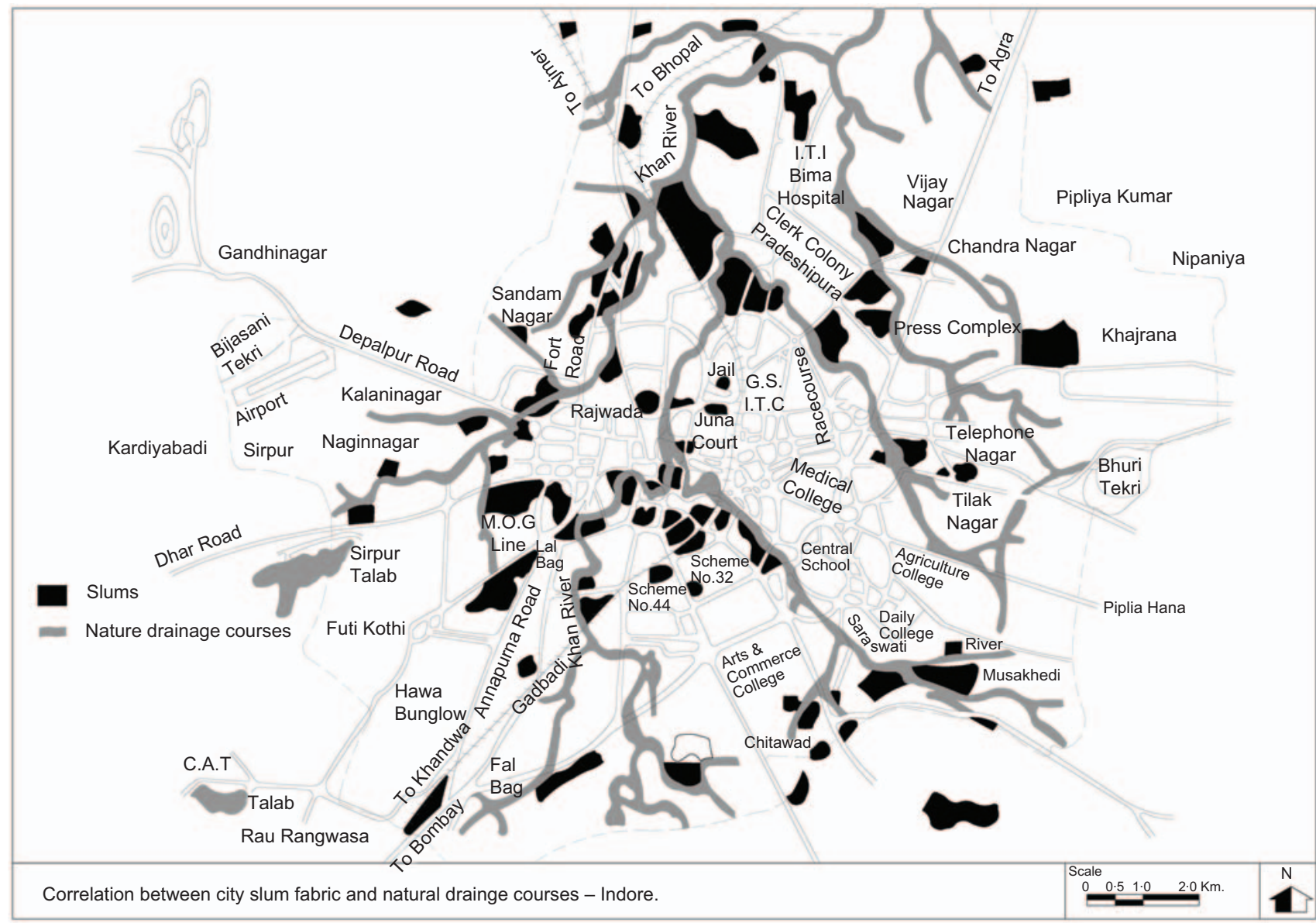

Figure 1. Slum networking concept (source: Himanshu Parikh Consulting Engineers)

the process. Thus slums, instead of being resource-draining liabilities as in the conventional developmental approach, become opportunities for bringing about a quantum change in the infrastructure levels and environmental quality of the city (Parikh, 1999). This co-ordinated process of treating the city slums as an urban net can replace the overlapping, and often conflicting, infrastructure developments which are currently being undertaken in a piecemeal way by a multitude of agencies (Sandhu, 1998) (see Figure 2).

At the micro-level slum networking provides integrated physical improvements, namely individual roads, water supply, storm drainage, sewerage, earthworks, electricity and soft landscaping. The various components of infrastructure are bundled for economy and integrated from slum to city level with respect to topography. This holistic approach is complemented by appropriate technologies and innovative details such as topography management, constructive landscaping, using roads as storm channels, miniature appurtenances such as gully trap connections, storm flushing of sewerage and ventilated manhole covers in lieu of vent pipes. 'The approach attempts to tap this latent strength for quality solutions in preference to substandard measures conventionally generated by the poverty mindset' (Parikh, 2005). Over a period of 6 years, the slum matrix of Indore city covering 450000 persons was upgraded with quality environmental and sanitation improvement (Parikh, 1999). The slums were integrated into the city fabric through the improved road and sewerage networks (see Figure 3). In addition to the 450000 recipient slum dwellers, a further 450000 citizens also benefited (Diacon, 1997).

Water and sanitation connections were provided on an individual basis so each slum dweller installed a tap and had an individual toilet as opposed to the conventional approach of providing a community-based toilet. The slum communities in India have maintained the household toilets and taps within the slum boundary for over 10 years. The evidence suggests 
Urban Design and Planning

Volume 166 Issue DP2
The role of infrastructure in

improving human settlements

Parikh, Parikh and McRobie
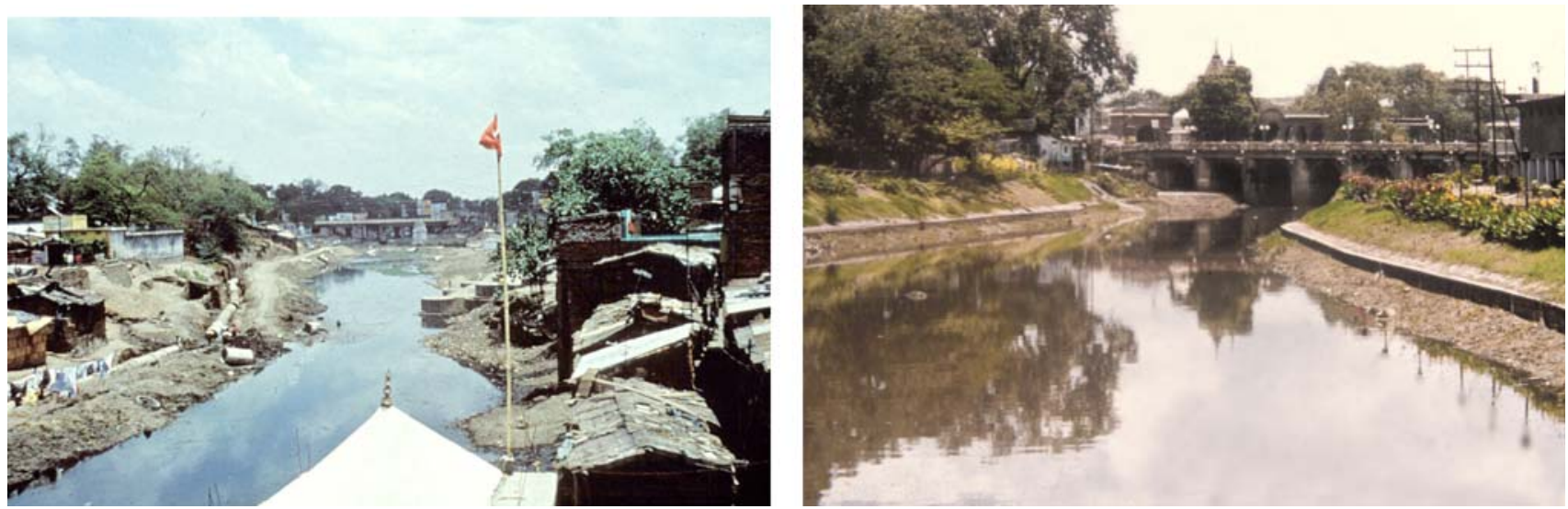

Figure 2. River in Indore before and after (source: Himanshu Parikh Consulting Engineers)

that there is a strong preference for individual water and sanitation facilities in lieu of common/shared/public water taps and public toilets. In India, privacy and dignity were cited as the main benefits of individual facilities. In South Africa, two reasons cited in the surveys in order of importance for the dramatic reduction in crime against persons are (a) private instead of public toilets and (b) street lights.

The concept of slum networking has since been extended to slums in other cities in India, some of which are used in the study here. Specifically slum networking was implemented in the Sanjaynagar and Pravinnagar Guptanagar settlements in Ahmedabad in 1997 and 1996-1998 respectively and in the Ramdevnagar settlement in Baroda city in 1996. While the project in Indore was funded by UKAid, the subsequent projects have been funded through local partnerships between

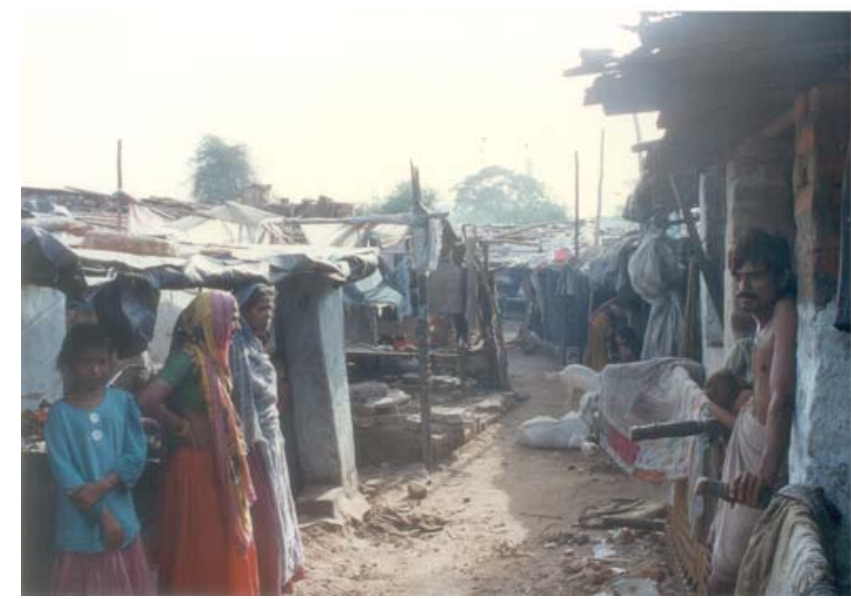

the slum communities, government, local businesses and local non-governmental organizations (NGOs). The approach of slum networking therefore has now evolved from a donorfunded to a self-funding model based on local public-private partnerships. The work was expanded to cover more slums by Ahmedabad Municipal Corporation (AMC).

As on December 2005, SNP has reached 8,703 families, making a significant contribution in the lives of 43,515 people in 41 slum communities of Ahmedabad. The community members have paid a total of US\$ 301,600 to the AMC as their contribution towards the services, something never done by slum dwellers anywhere else in India. (AMC, 2005)

The economic conditions in the serviced slums of Sanjaynagar, Ramdevnagar and Pravninnagar Guptanagar settlements were

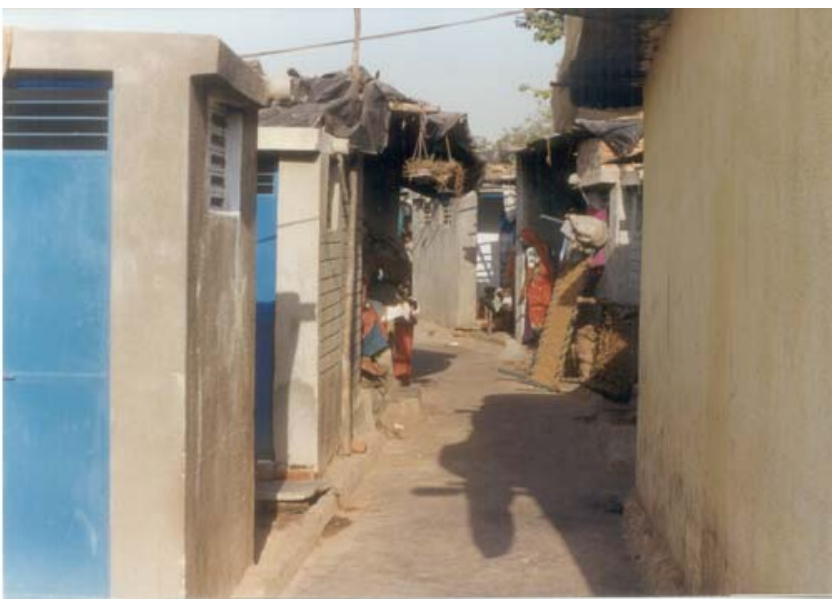

Figure 3. Slum before and after (source: Himanshu Parikh Consulting Engineers) 
Urban Design and Planning

Volume 166 Issue DP2
The role of infrastructure in

improving human settlements

Parikh, Parikh and McRobie compared with those in two control slums (Khokra and Hansol) in Ahmedabad, which had not received any upgrading, and with a township (Imizamo Yethu) in Cape Town, South Africa, part of which had been upgraded (albeit not by the slum networking concept) and part of which had not. In 2003 Niall Mellon Township Trust looked for 150 volunteer Irish builders to go to the South African township of Imizamo Yethu and build housing (UTV, 2005). This operation expanded and more volunteer builders joined in to build housing and the government joined in as well to provide infrastructure after a fire in February 2004.

\section{Methodology}

Five slums in India and two South African township sites were selected for the study. Three of the five case study slums in India (Ramdevnagar, Sanjaynagar and Pravinnagar settlements) were selected on the basis of having household water and sanitation provided in the last 10 years, and data collection was conducted for the socio-economic situation in the years of 1996 (no services) and 2006 (serviced). The data for 1996 were obtained during the interviews conducted in 2006 and based on the respondents' knowledge and experience. The same households had been living in the settlements throughout the study period. The household composition had remained unchanged in the South African townships. In the Indian slums the family sizes had increased from an average of 4.82 to $6 \cdot 10$ in the three serviced settlements. The increase in the family size is a result of an increase in children. The participation (workers) ratio which shows the proportion of working population to the total has not increased significantly in the serviced slums. Hence the changes in household income and expenditure were not due to the change in family sizes and household composition.
The two settlements of Khokhra and Hansol were nonserviced. One of the settlements (Hansol) has been designated as the 'control slum' with data collection for the years of 1996 and 2006. The changes in the control slum of Hansol have been compared to the serviced slums to map out the differences that may be attributable to services. In South Africa the township of Imizamo Yethu had one portion with houses and services, and the other portion with non-serviced shacks. The serviced and non-serviced portions have been treated as two separate townships and data have been collected for the year of 2004 (non-serviced) and 2006 (serviced) in the developed part of the township with houses. For the shacks in Imizamo Yethu, data were collected for the year of 2006. Table 1 gives details of the communities interviewed.

Evidence was collected through semi-structured interviews and 700 house interviews in the seven settlements (see Figure 4). The surveys took the form of face-to-face house interviews with questionnaires. The semi-structured interviews were conducted in all the study slums with a group of 15-20 men and women, and were used to modify and fine-tune the pilot questionnaires. The improved questionnaire was then repiloted in one house for each case study. The questionnaires were used to collect both qualitative and quantitative evidence from the communities. Random sampling techniques were used to ensure that a representative sample was interviewed.

The questionnaires were in English and the survey team was trained to ask the questions in the local language but to record responses in English. This eliminated the need for translation. The survey teams in both countries were literate graduates with fluency in both English and local languages. The team

\section{Case study}

Sanjaynagar

Ramdevnagar

Pravinnagar

Khokhra

Hansol

Imizamo Yethu,

serviced

Imizamo Yethu,

non-serviced
No. of dwelling units (community amenities included)

\footnotetext{
a Source: Himanshu Parikh Consulting Engineers.

bSource: Ahmedabad Municipal Corporation (2005).

'Source: Discussion with community leader Kenny on 20 August 2007.
}

Table 1. Profile of case study slums 

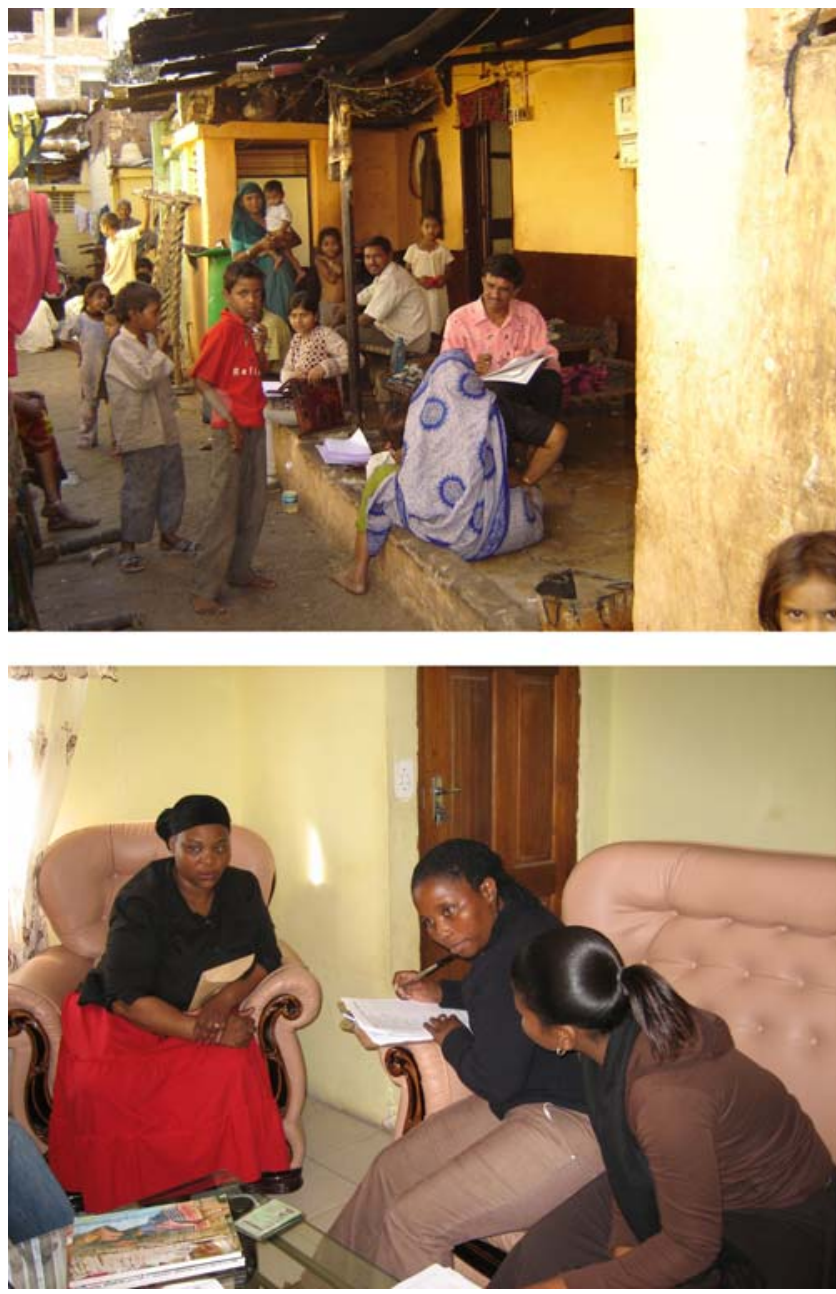
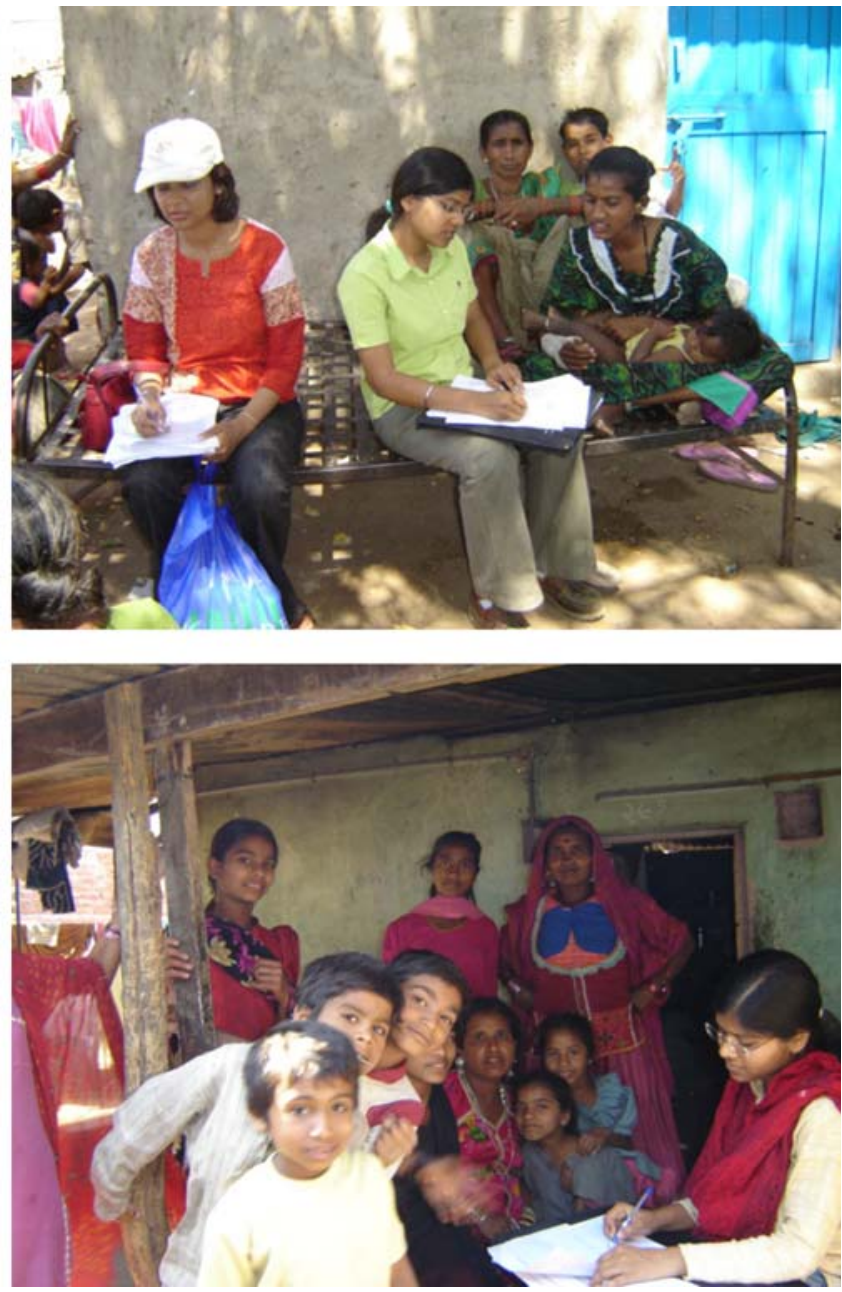

Figure 4. Socio-economic interviews (source: Parikh (2008))

members were enthusiastic and committed. A friendly downto-earth approach enabled the team to break the ice and extract personal data which is normally quite challenging to obtain.

A face-to-face interview format was adopted as it was felt that a postal survey would not have the same response. Mailing is difficult in slums as some shacks do not have formal addresses. While time is of great value in slums and townships, residents do co-operate and respond to face-to-face interviews. Participation was unproblematic in this study despite the difficult and personal questions posed during the house interviews.

On average, each house interview took 40-50 min to complete. Objectivity was achieved by ensuring that the questions were not leading in nature, and some questions were repeated in different sections as a check that the respondents were consistent. In order to ensure an even coverage of male and female respondents the interview timings were split between morning, afternoon and evening hours. In the non-serviced settlements mornings were not a good time for the survey as most of the houses were busy with water collection activities, with women predominantly away from houses. In contrast, mornings were a good time for interviews in the serviced settlement as both men and women went to work during the day and were at home during mornings.

\section{Impact}

This section will look at the impact of integrated infrastructure (water and environmental sanitation) provisions on health, education and disposable incomes for communities.

\subsection{Health}

One way of assessing impact on health is to look at the household expenditure on medicine (medicine and doctors' 
Urban Design and Planning

Volume 166 Issue DP2
The role of infrastructure in

improving human settlements

Parikh, Parikh and McRobie fees). While this is an indirect measure, it does indicate whether there has been a change in the monetary effort required by the families to stay healthy. For all the serviced case studies, information on monthly household spending on medical treatment was collected both before and after services, while for the non-serviced houses information on current medical household spending has been collected for comparison purposes (see Figure 5). The 1996 costs for medicines were inflated to 2006 prices for the comparison.

The survey results show that medical expenses have decreased in all developed slums in India, and current medical expenditure is lower than that in the non-serviced slums of Khokhra and Hansol. Similarly, medical expenses have been reduced in the developed township, although the magnitude of the change is smaller because the difference is measured over a 2 year period rather than the 10 year period in India. Medicine is subsidised by the government in South Africa, with patients being offered means-tested healthcare subsidies based on income, so overall there is low expenditure on medicine (Cape Gateway, 2008). In the non-serviced settlement of
Imizamo Yethu the residents make exclusive use of the subsidised medical provisions.

In all the three developed slums in India there is a shift toward lower spending on medicines and the money saved on medicine could be used as savings for housing upgrading and other activities. The reduction in medical spending has a potential knock-on effect on other parameters of development. In Ramdevnagar and Pravinnagar, in spite of the earlier NGO presence and private health clinics, the medical expenditure decreased after water and environmental sanitation provisions, indicating that this is an additional impact. In Ramdevnagar where no such facilities existed, an attempt to establish a clinic failed and yet health improved after infrastructure provision, indicating that direct medical intervention was not the cause of change. In Hansol, where there is no development, the medical expenses have increased in the last 10 years, possibly negating the argument that natural economic growth could be a reason for improved health in the community.
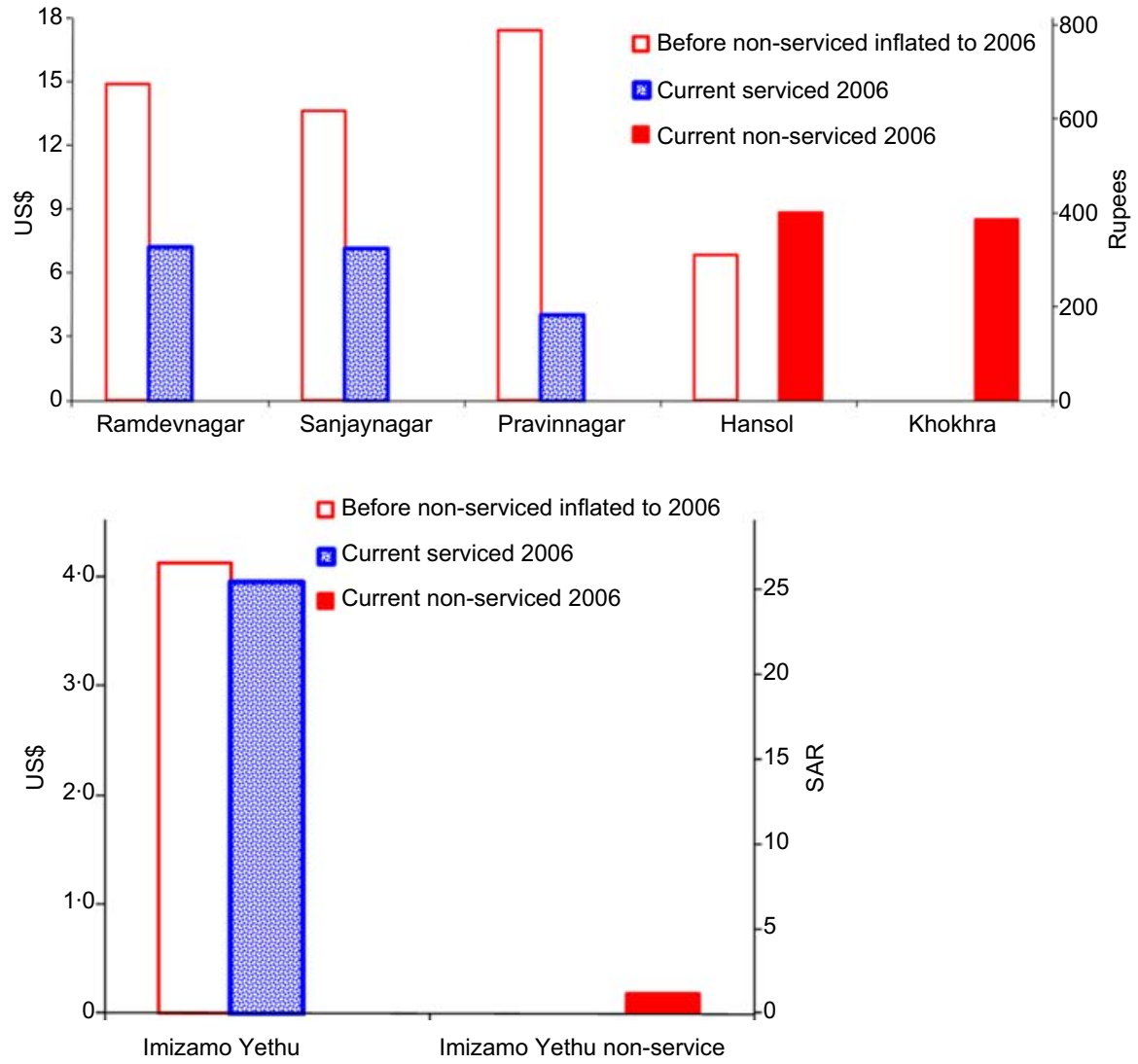

Figure 5. Average household monthly medical spending (source:

Parikh (2008)) 


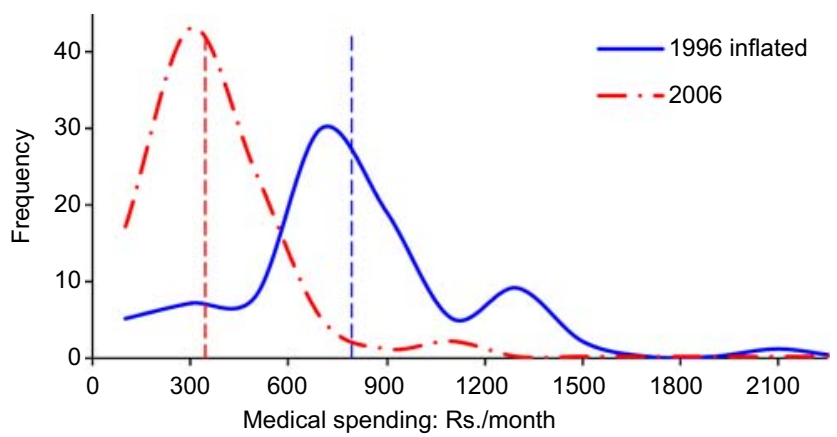

(a)

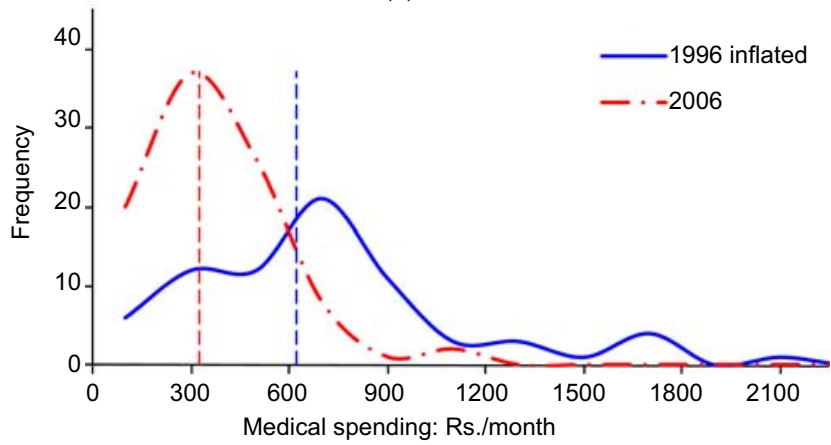

(b)

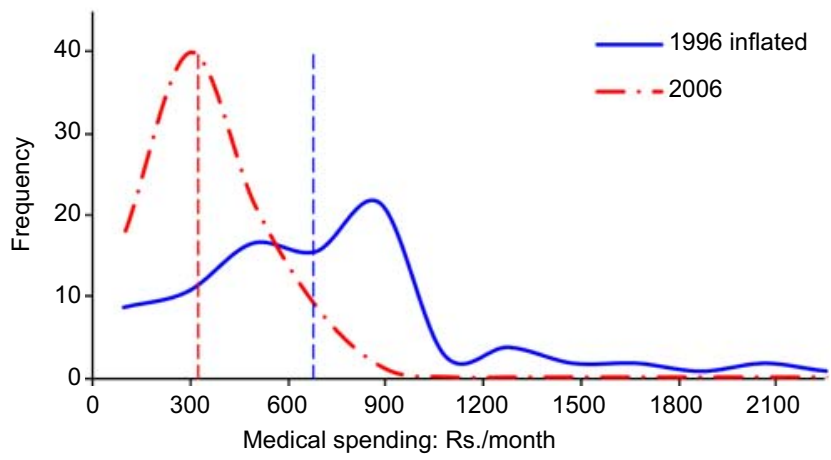

(c)

Figure 6. Trends in medical spending (source: Parikh (2008)),

medical spending distribution in: (a) Sanjaynagar; (b) Pravinnagar;

(c) Ramdevnagar

Figure 6 shows the shift in the distribution of medical costs towards lower levels demonstrating that the reduction in medical expenses is valid for the large sample surveyed in India. Since the only common intervention in India has been integrated infrastructure it can be argued that infrastructure may have a role to play in the reduction of medical spending. The South African settlement was not plotted as it did not have a large variation in household medical costs before and after, and medical costs were subsidised by the government.

\subsection{Education}

It was difficult to obtain reliable school attendance figures from nurseries and schools in the vicinity of the case studies, as the local administration did not have systematic records of school attendance. Most of the secondary sources use school enrolment to measure literacy rather than the ability actually to read or write. Although school attendance numbers would give an indication of the enthusiasm for education, they are not necessarily a measure of literacy and information gathering (Dasgupta, 1993). Therefore, the ability to read newspapers 
Urban Design and Planning

Volume 166 Issue DP2
The role of infrastructure in

improving human settlements

Parikh, Parikh and McRobie has been used as a measure of functioning literacy. The census of India (Census, 2001) defines literacy as the ability to read or write one of the 15 official languages in India and also includes English/Hindi. In the survey here, respondents were asked how many family members could read newspapers either in their local language or English. The percentage of those with this level of reading ability was obtained by dividing the total number of readers by the population aged 5 years and over.

Figure 7 shows that in India there is a significant improvement in literacy in the serviced slums after provision of services $(p<$ $0 \cdot 0001)$, and also in comparison to the non-serviced slums $(0<$ $p<0 \cdot 05)$, despite the fact that there was no increase in the educational infrastructure in those slums. In South Africa the differences are not significant as the basic literacy there was universally high to begin with.

\subsection{Disposable income}

As people are often reluctant to reveal their incomes, these can be difficult to measure. Reported incomes have thus been cross-checked against measurements of family to arrive at 'disposable income' per month (see Figure 8). The current monthly spend of families was estimated from monthly medical expenses, food, grocery, clothes, education costs, bills, electricity charges, cable TV costs and investments in vehicles and housing (Parikh, 2005). In the calculations for monthly income, pensions have been added to the reported income. However, it was not possible to add other informal sources of income such as barter, food or clothes for work, livestock income and so on. The disposable income should, therefore, be slightly underestimated. As this income is based on expenditure, the retail consumer price index has been used to inflate it to par. The disposable income estimates match well with reported income but as expected are slightly lower. Disposable incomes have increased in all the serviced settlements, with the rate of increase much higher than the control non-serviced slums both in India and South Africa.

While one argument for the increase in incomes could be the natural economic growth, the current incomes in the serviced slums are higher than the 'before' incomes (allowing for wage inflation) and they are higher than the current incomes in unserviced slums. There appear to be no other noticeable causes between the 'before' and 'after' or between the serviced and unserviced to account for this difference, other than provision of infrastructure.

Group discussions show how respondents clearly perceive water and sanitation as a factor influencing incomes, as freed time and fewer days lost to illness increase earnings, and lesser
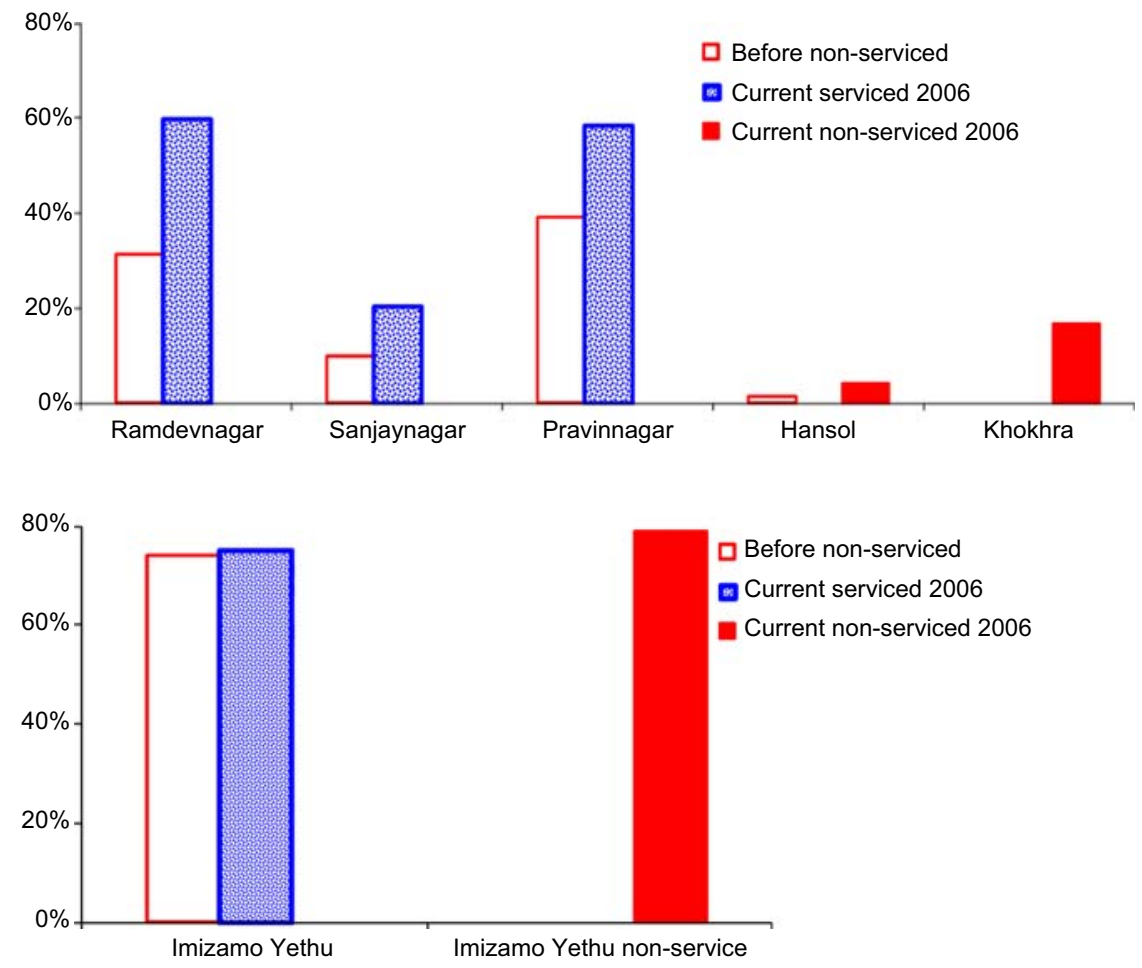

Figure 7. Percentage newspaper reading in $5+$ age group (source:

Parikh (2008)) 

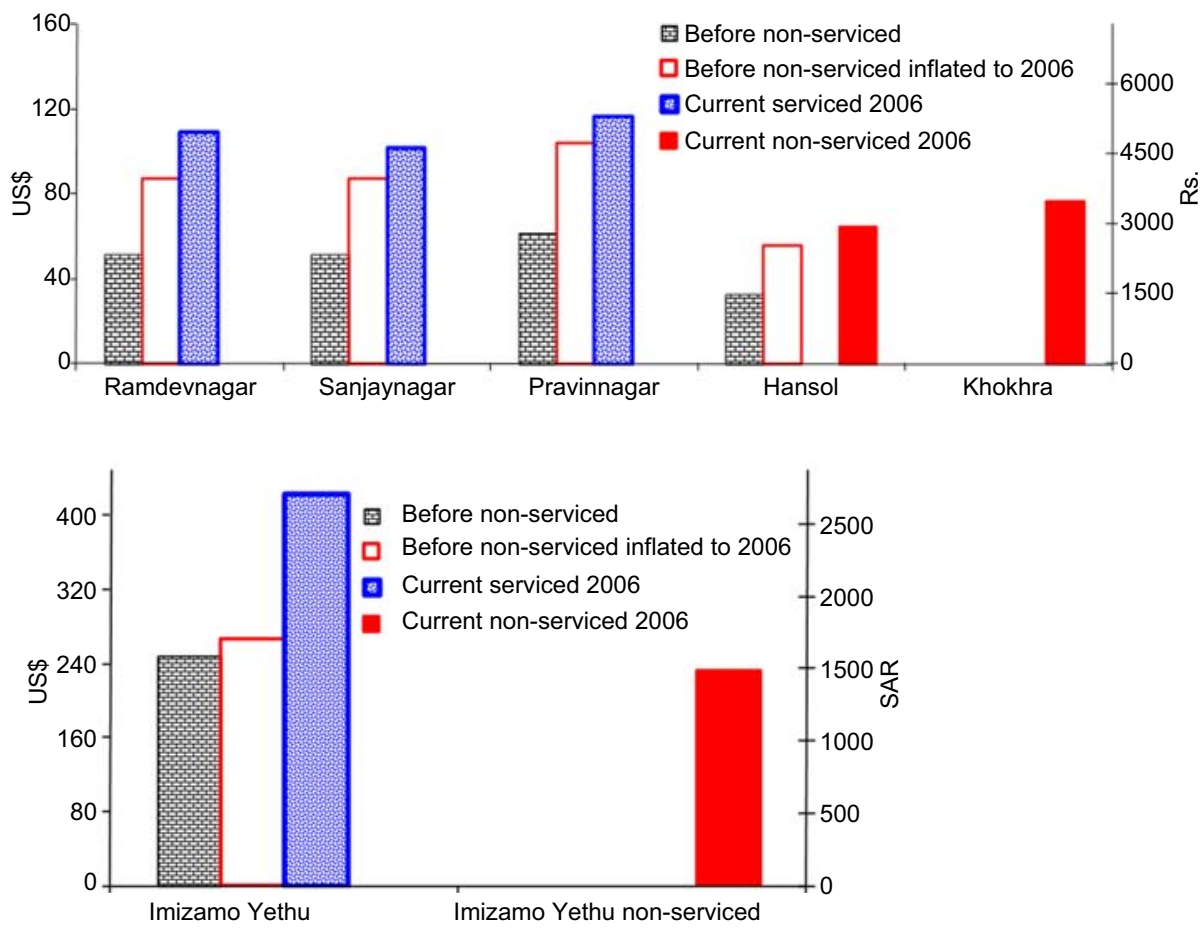

Figure 8. Monthly disposable incomes (household monthly calculated expenditure) (source: Parikh (2008))

medical expenses increase savings. Bad health and greater incidence of illnesses result in a reduction of work days as people have to stay at home. Also parents lose work days if their children are ill and need attention.

A study by SEWA (2002) shows an increase in average working hours after the provision of water and sanitation. The respondents acknowledge that the provision of water and sanitation has resulted in increased productivity and incomes (SEWA, 2002). Respondents in the unserviced slums have explained how the crucial morning hours were lost in water collection.

\section{Priorities}

The purpose of the ranking exercise was to make an assessment of community preferences for various components of services and housing as opposed to the softer inputs in health and education. The respondents were asked to rank ten items (water, sanitation, roads, electricity, storm water drainage, housing, education, health facilities, employment) before and after project implementation. The highest priority item was ranked as 10 and the lowest priority item was ranked as 1 . The question posed to the residents was 'If they had money (\$1) to invest what would be the most important item and then second and third most important and so on', encouraging residents to make a difficult choice regarding their priorities. As the number of responding houses for each case study varied, the summation of ranks of each item from all the houses in each case study was divided by the number of responding houses to ensure an equal comparison.

In the serviced settlements the respondents were first asked to rank all ten items as if they had been asked the question before the infrastructure was implemented. However, for the postimplementation scenario some of the respondents found it difficult to rank services, as they already had service provisions. The non-responding items were assigned equal ranks. Thus, if only two items have been ranked then the sum of their ranks would be $10+9=19$. This means that the remaining eight items should have a total rank of $55-19$ where 55 is the sum of the ranks 1 to 10 . For the remaining eight items the uniform rank would be $55-19=36$ divided by 8 which gives $4 \cdot 5$.

In all the non-serviced slums and for the hypothetical nonserviced scenario in serviced slums respondents gave top priority to investments in water and sanitation infrastructure in preference to housing, health, education and employment (see Figure 9). This is reinforced by the reversal in priorities from infrastructure to other segments once the physical development work was done in the serviced slums. In Pravinnagar $89 \%$ of the survey respondents contributed to 
Urban Design and Planning

Volume 166 Issue DP2
The role of infrastructure in

improving human settlements

Parikh, Parikh and McRobie

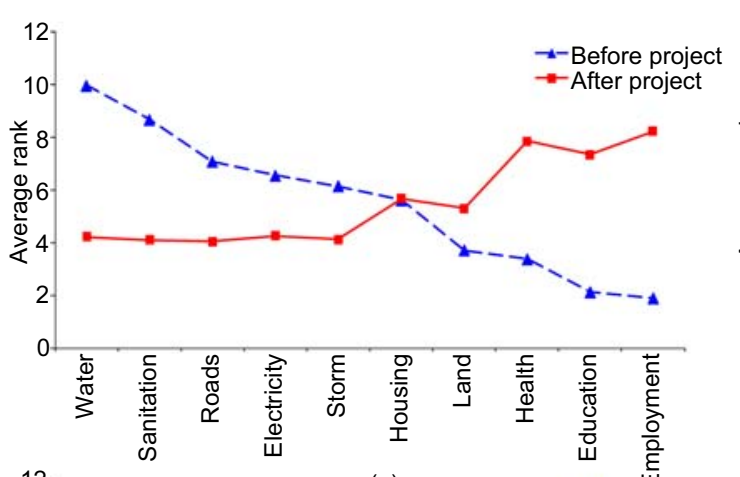

(a)

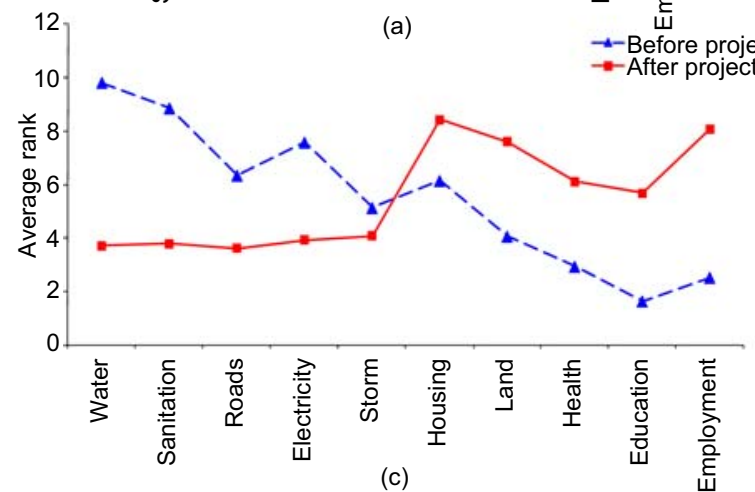

(c)
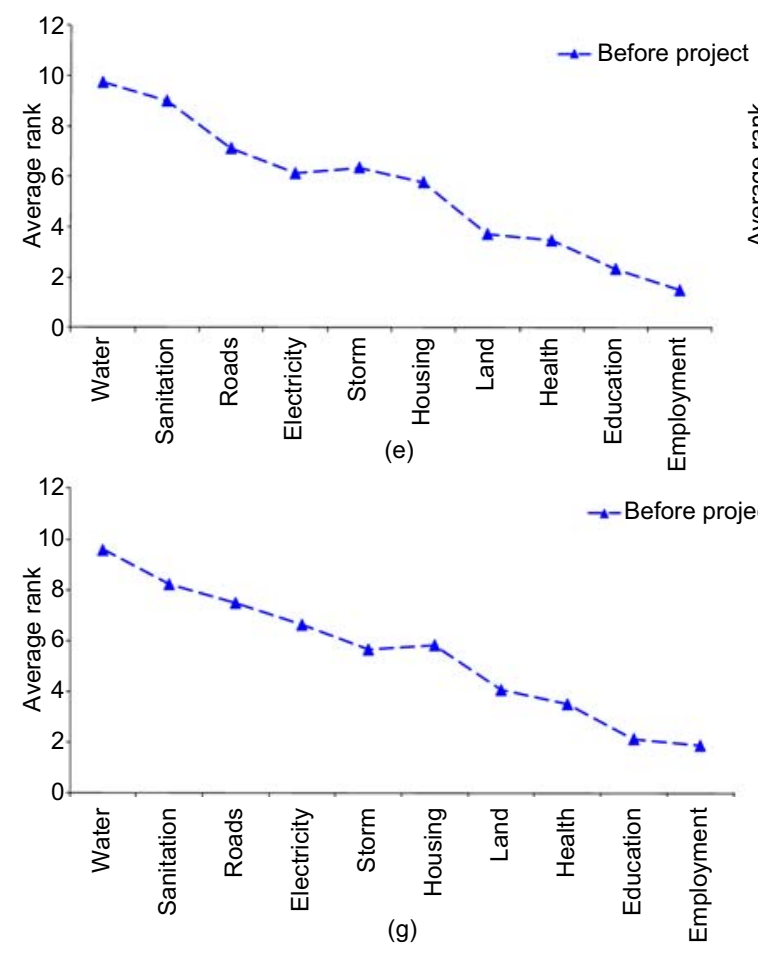

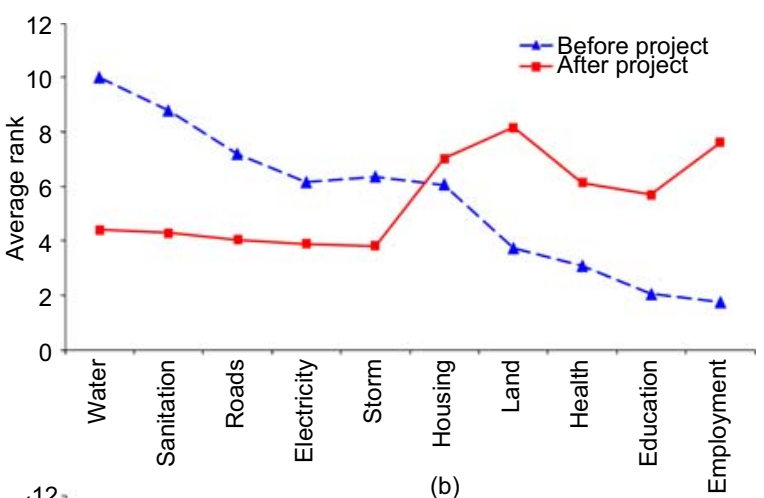

(b)

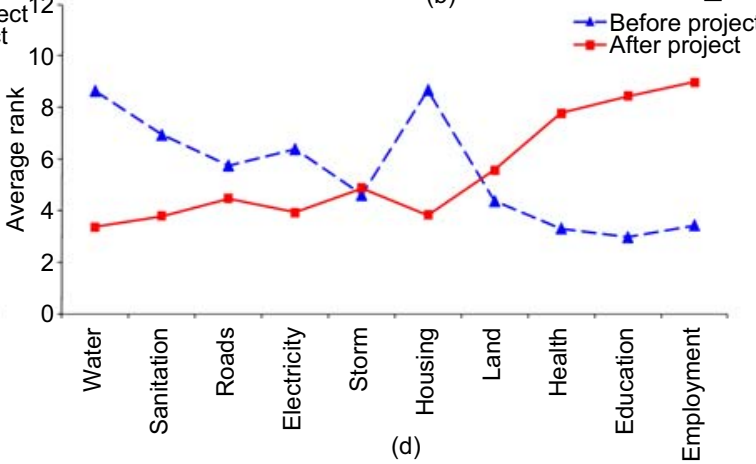

(d)

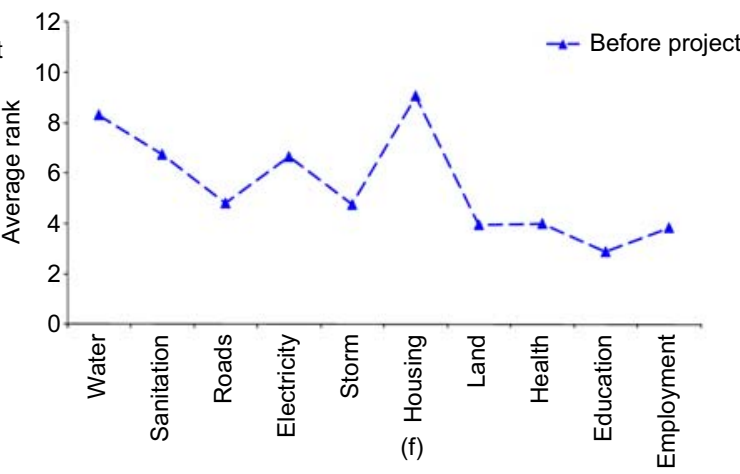

Figure 9. Community priority of investment ranking - India and South Africa (source: Parikh (2008)): (a) Pravinnagar; (b) Ramdevnagar; (c) Sanjaynagar; (d) Imizamo Yethu serviced; (e) Hansol; (f) Imizamo Yethu non-serviced; (g) Khokhra 
the slum networking project because they wanted better services (Joshi, 2002). The community perceptions are in contrast to the perceptions in most development agencies that, while water and sanitation are important, priority investments should be in other sectors such as health, education and governance. While professing community participation and grass roots planning, it is ironic that the developmental scene is discordant with people's wishes.

For the township of Imizamo Yethu the priorities before the project were housing, water, sanitation, electricity and roads. After implementation health, education and employment became high priorities. Unlike the settlements in India, the residents of Imizamo Yethu put equal emphasis on both water and housing, the mindset being that the government should provide housing. In fact, the project brief in the township of Imizamo Yethu does include housing along with water and sanitation infrastructure. However, this means that the government is not using its resources efficiently, as it could have generated the housing resources from the community instead of providing the part subsidy for housing (Parikh and McRobie, 2009). The part subsidy for housing instead could have been utilised in another township for the provision of services. An evaluation of a housing scheme in Madras, India implemented by HUDCO (Housing and Urban Development Corporation) shows that the local communities valued environmental sanitation, clarity on land tenure and socioeconomic benefits, and that merely building housing on its own was not enough (Sethuramalingam, 1998).

\section{Multiplier}

In all four of the developed slums the community made a sizeable contribution to the initial capital investment (see Figure 10). If one adds to this the contribution from other partners, the community and private sector funding surpasses the state component in most of the study cases. For all four slums development has been possible without external aid funding (except for 30\% UNICEF contribution in Ramdevnagar). Furthermore, in all these cases development has taken place with current and established financing instruments which are extendable to a larger population. This inherent resource strength is still not fully understood and the developmental mindset is still locked into notions of resource constraints and aid dependency. The sustainability of this approach is clear in Ahmedabad where an initial pilot has grown into a 41-slum programme with its own momentum (AMC, 2005). The house interviews show that in the slums yet to be developed, people have indicated a willingness to pay for service provisions both in terms of initial lump sum outlay and monthly installments, the preference in South Africa being for lump sum payment.

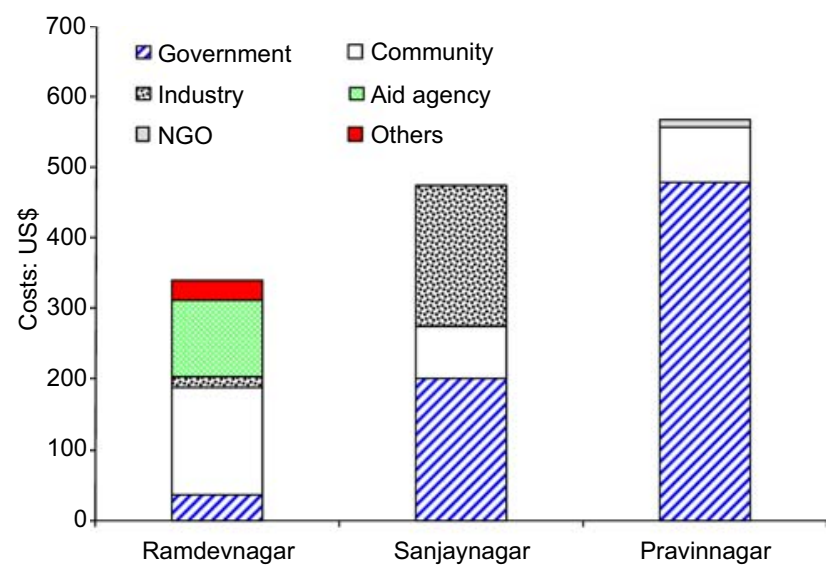

(a)

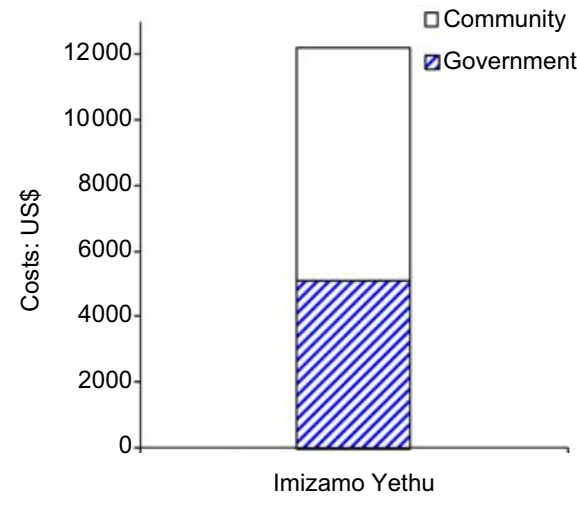

(b)

Figure 10. Project costs for infrastructure provisions (inflated to 2006): (a) infrastructure and toilets in US dollars; (b) infrastructure and housing in US dollars (source: for Ramdevnagar, UNICEF

(1999) costs; for Sanjaynagar, Tripathi (1998), Alliance for Change (1995) costs; for Pravinnagar, AMC (2005); for Imizamo Yethu, discussion with community leader Kenny on 20 August 2007; costs are 2004)

In all of the serviced settlements, most of the house walls are now brick in place of the previous mud walls and the flooring has improved to plastered or tiled flooring from the previous mud floors. Most of the non-serviced slums and townships still have mud walls or tin sheets. The house roofs have been converted from tin sheets to concrete with more than $50 \%$ of houses having concrete roofs in Pravinnagar. Surveys in Pravinnagar by SAATH also show that $55 \%$ of roofs have been redone after project implementation and $72 \%$ of houses have had plumbing and electrical fittings added or redone (Joshi, 2002). The housing stock has either been upgraded or extended with residents using on average Rs. 50250 in the form of savings or loans from relatives (Joshi, 2002). De Soto (2000) tried to track down cement sales as an indication of building activity in Brazil. The construction industry reported a 
Urban Design and Planning

Volume 166 Issue DP2
The role of infrastructure in

improving human settlements

Parikh, Parikh and McRobie negligible growth rate of $0 \cdot 1 \%$ in 1995 but the cement sales soared by $20 \%$ in 1996 due to increased buying by poor residents to build their houses. These figures are not officially recorded, and hence housing investments by low-income communities is never truly reflected in the government published figures for growth.

As shown in Figure 11, after the initial infrastructure investment the community has put in amounts ranging from US\$ 1500 to 3000 in India for improving and expanding their housing from their own sources. In South Africa the community is paying back the total costs of infrastructure and housing in the form of a 10-year loan. The total amount being paid back by the South African community is about US\$ 7000 .

Unlike the initial investment which is largely dependent on microfinance, the subsequent spending depends more on savings and loans. CEPT (2004) study shows that $43 \%$ of respondents in serviced slums borrow from relatives for home improvements and only $9 \%$ currently go to a bank or financial institution. Socio-economic surveys in Pravinnagar also show that respondents borrow from the work place for financing housing upgrades (Joshi, 2002). The 'assumed' poor have found an entire network for funding which remains largely unrecognised in developmental strategies (see Figure 12). Sometimes markets see these potentials early on, and in India, for example, the formal banking sector has now entered into microfinance with the leading banks like ICICI and HDFC spearheading the move.

The house interviews showed that subsequent housing investments by the people were predominantly in converting temporary or semi-permanent shanties to permanent brick and concrete buildings. These changes are far greater in slums with infrastructure provision both in India and South Africa than the undeveloped slums, in spite of similar land ownership and tenurial situation. This is reinforced by the reasons people cite for their subsequent investment in developed slums (see Figures 13 and 14). Infrastructure investment is cited as the dominant motivator in about two-thirds of samples, while security of tenure is cited as the least important factor varying from 0 to $8 \%$. In South Africa, owing to local circumstances, personal safety is cited as the principal reason for subsequent investments, although even there about one-fifth of the sample cite infrastructure as a causative factor. According to Payne (2001), poor people risk investing in housing activities on plots of land where urban authorities try to evict
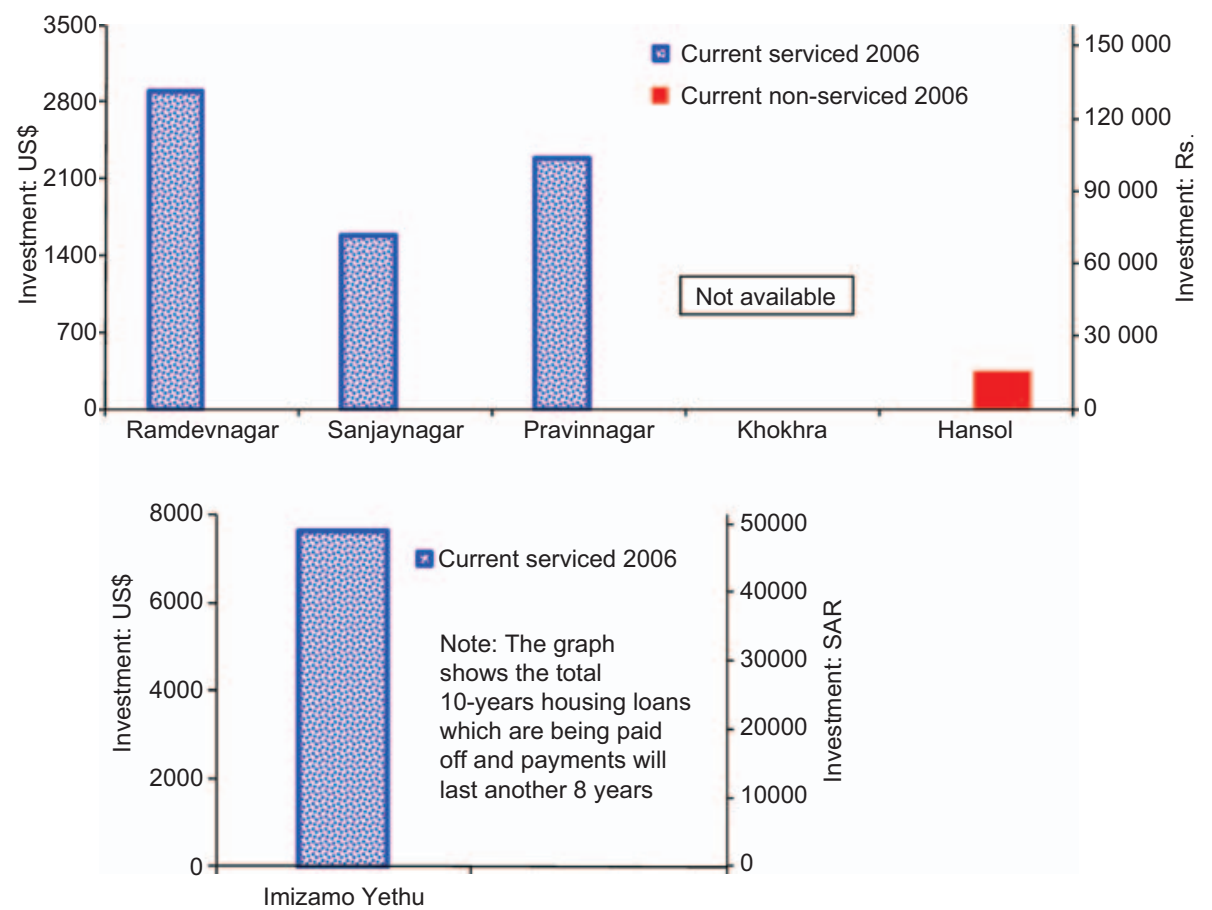

Figure 11. (a) Household and goods investment by community from 1996 to 2006; (b) household, goods and infrastructure investment by community from 2004 to 2006 (source: Parikh (2008)) 

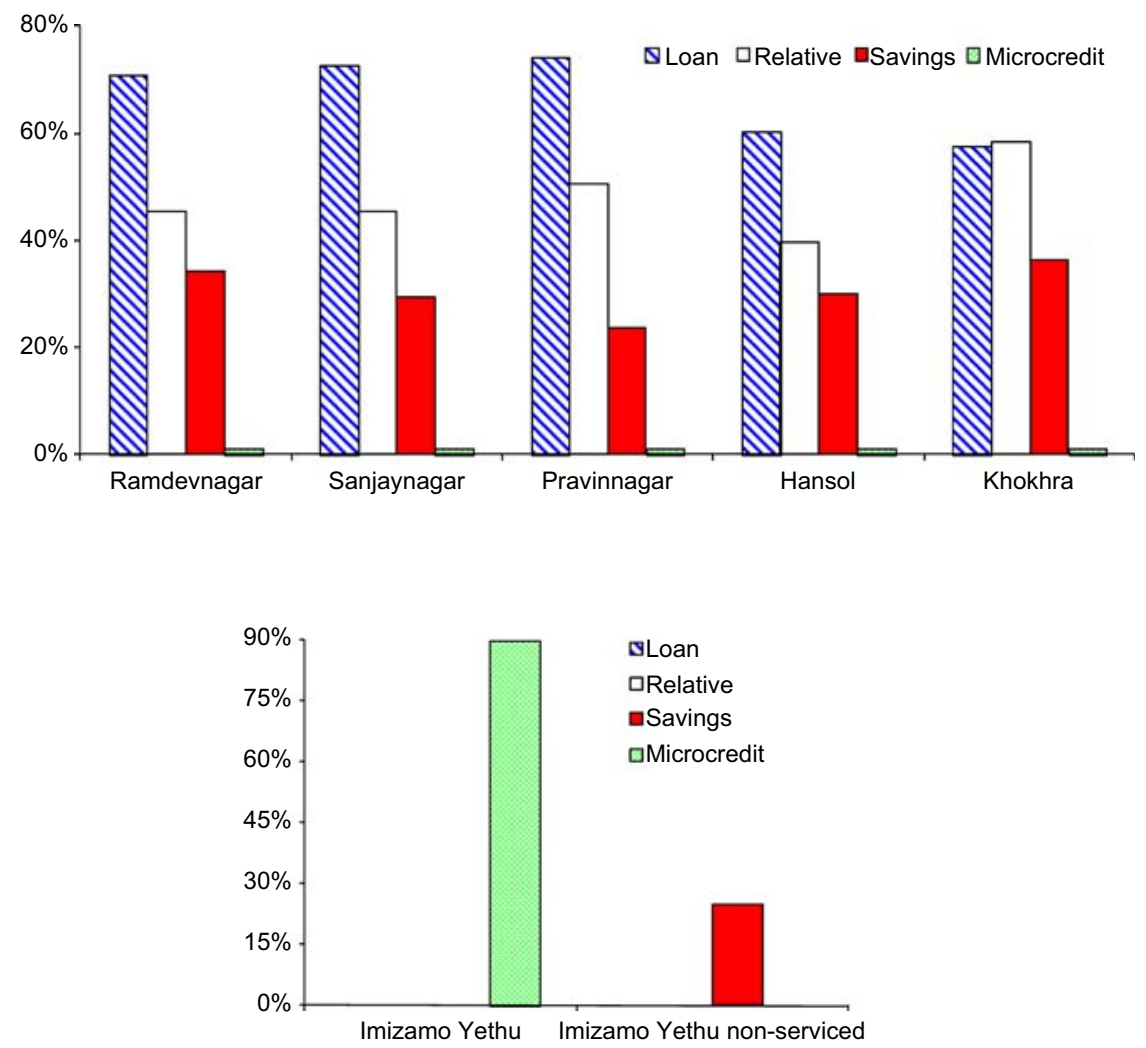

Figure 12. Source for housing investments by community (source: Parikh (2008))

them, because they have little choice. Land near the employment zones is expensive, and if the poor move out to the periphery of the city they are penalised through high transportation costs.

Community investments in housing, assets and infrastructure have been measured for the developed settlements and the control settlement of Hansol. The housing investments have been calculated by measuring changes in housing areas and materials (from 1996 to 2006 for India and 2004 to 2006 for South Africa) and multiplying these by the construction costs of the relevant components such as walls, flooring, roofing and so on. A similar methodology has been adopted by De Soto (2000) and his team for determining building values in informal settlements. An area for toilets was deducted from the calculation wherever these were funded and constructed by the government. The list of assets obtained from the interviews was used to calculate the investment by respondents in goods. Rates from 2006 are assumed for all the assets and goods within the house. Information about community investments in the initial infrastructure provisions was obtained from secondary sources. The specific data and assumptions for each case study are described below.
Pravinnagar Guptanagar 1: according to AMC sources the actual infrastructure costs inflated to 2006 were Rs. 25721 (US\$ 567). Of this, AMC contributed Rs. 21651 (US\$ 477) for the costs of infrastructure. AMC also contributed an additional Rs. 5215 (US\$ 167) for the construction of individual toilets. The community contributed Rs. 3561 (US\$ 78.5) and the NGOs contributed Rs. 509 (US\$ 11.5). The community contributed to $100 \%$ of the cost of housing improvements (excluding toilets) and purchase of household assets.

Sanjaynagar: according to AMC sources the infrastructure costs inflated to 2006 were Rs. 8420 (US\$ 493). The cost of infrastructure was split equally between $\mathrm{AMC}$, slum community and the business partners Arvind Mills. In addition, AMC and Arvind Mills jointly shared the costs of toilet construction, which amounted to Rs. 8684 (US\$ 191) in 2006. The community contributed $100 \%$ of the cost of housing and purchase of household assets.

Ramdevnagar: according to UNICEF (1999) the inflated costs for infrastructure in 2006 were Rs. 15380 (US\$ 339). The residents constructed the toilets themselves and also contributed $44 \%$ of the cost of infrastructure. The residents also 

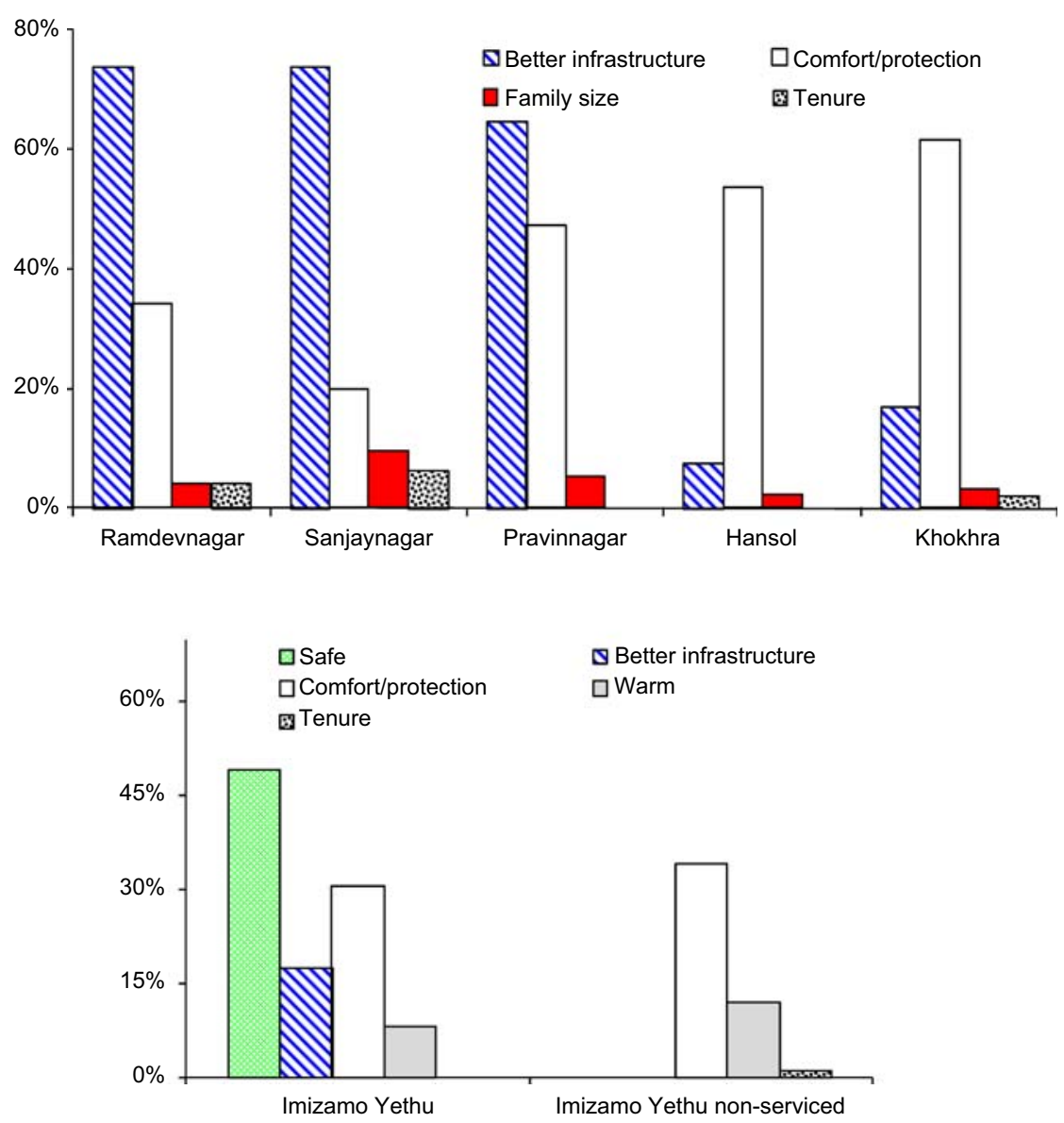

Figure 13. Reasons for community investment into housing

(source: Parikh (2008))

contributed $100 \%$ of the cost of housing improvements and purchase of household assets.

Imizamo Yethu: for Imizamo housing was part of the project as the government-provided subsidy for full infrastructure and partial housing cost. Based on discussions with local government officials and household interviews the infrastructure subsidy along with land development was SAR 15000 (US\$ 2537 ) in 2006. The subsidy for part housing and land from the government along with infrastructure adds to SAR 32490 (US\$ 5075) in 2006. The Niall Mellon Trust then provided 10year loans to the community for the full costs of housing and infrastructure. The community are therefore paying back SAR 45392 (US\$ 7091) to the Niall Mellon Trust. The trust therefore can channel resources to other settlements. The housing was not built by the community themselves but by builders, in a standard format. Information on goods such as television sets had been obtained for both the houses and nondeveloped shacks. The assets for houses were roughly double the assets found in the shacks. It has been assumed that $50 \%$ of the assets in houses were brought by communities after provision of housing and infrastructure.

When measured after a period of 10 years in developed slums in India, the total investment by the community as a factor of initial state investment is enormous (see Figure 15). In fact it is so large that almost all of the ultimate investment is done by the slum communities themselves and the initial state contribution seems insignificant. The assumed 'weakest link' in the resource chain, namely the poor, eventually turns out to be strongest and dismisses all arguments about paucity of resources for development and dependence on aid. Even in South Africa where resources are seen as the state's responsibility, the community has, in the 2 years, already managed to mobilise a greater share of investment than that of the government and in the coming years, with continuing community investments, the ultimate picture is likely to resemble that of India. 


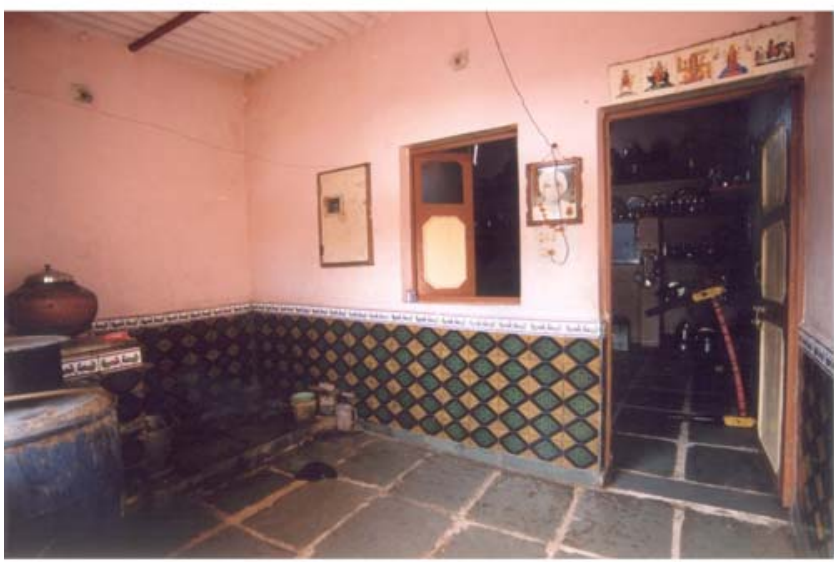

(a)

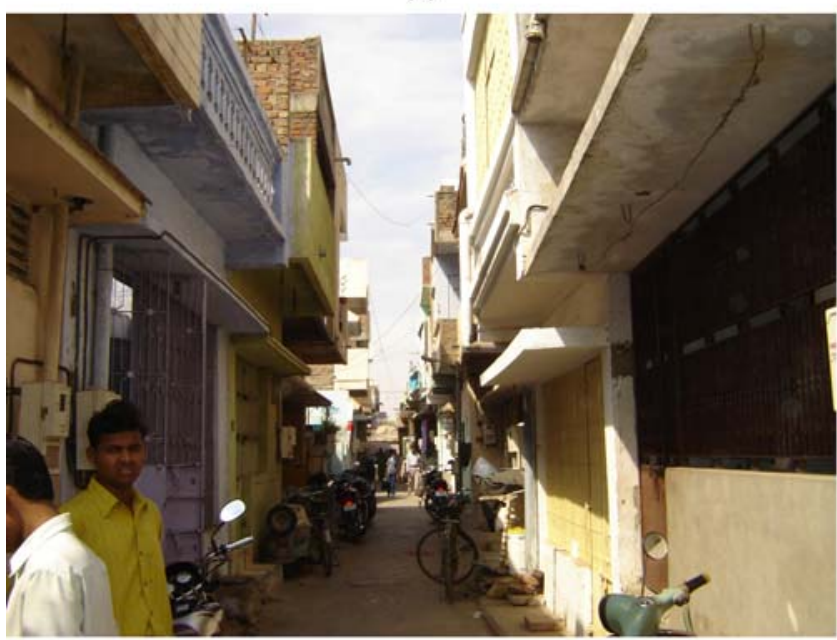

(c)

Figure 14. Upgraded housing: (a) upgraded house interior in Sanjaynagar; (b) upgraded house interior in Sanjaynagar; (c) Pavinnagar shacks upgraded to houses (source: Parikh (2008))

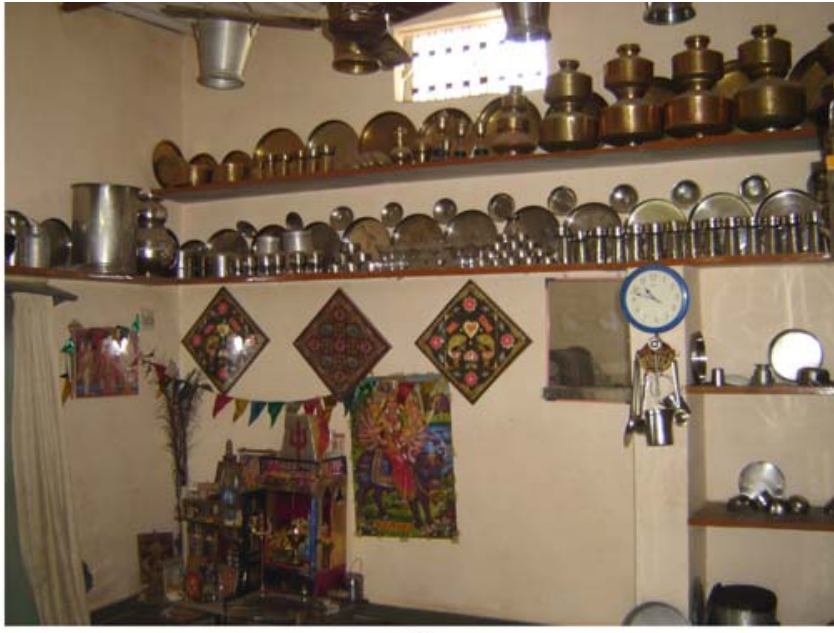

(b)
The multiplier, as above, is defined as the ratio of the community investments in housing, goods and infrastructure to (a) government investments in infrastructure and (b) total cost of infrastructure (see Figure 16).

For the settlement of Ramdevnagar, a multiplier of 85 is observed indicating how the community generated 85 times the resources compared to the government investment. This value is equivalent to 8 times the total cost of infrastructure. In the settlement of Sanjaynagar a multiplier of 8.23 was obtained with respect to government investment in infrastructure and in Pravinnagar 4.94. In Pravinnagar, government investments were very high, and therefore the full potential of community investments has not been realised. In the South African township of Imizamo Yethu, where the government partly funded housing, the multiplier reduces to $1 \cdot 51$. There is a loss of economy of scale in built housing schemes resulting in high construction costs, as compared to housing constructed by the communities themselves.

\section{Conclusion}

The evidence presented in this paper shows that there is an improvement in health, education and incomes after the provision of integrated in situ water and environmental sanitation infrastructure in slums and townships.

There have been community investments in housing stock in the Indian case studies after the provision of services. In South Africa, the project scope included housing construction, but the community has been paying back the housing costs in the 

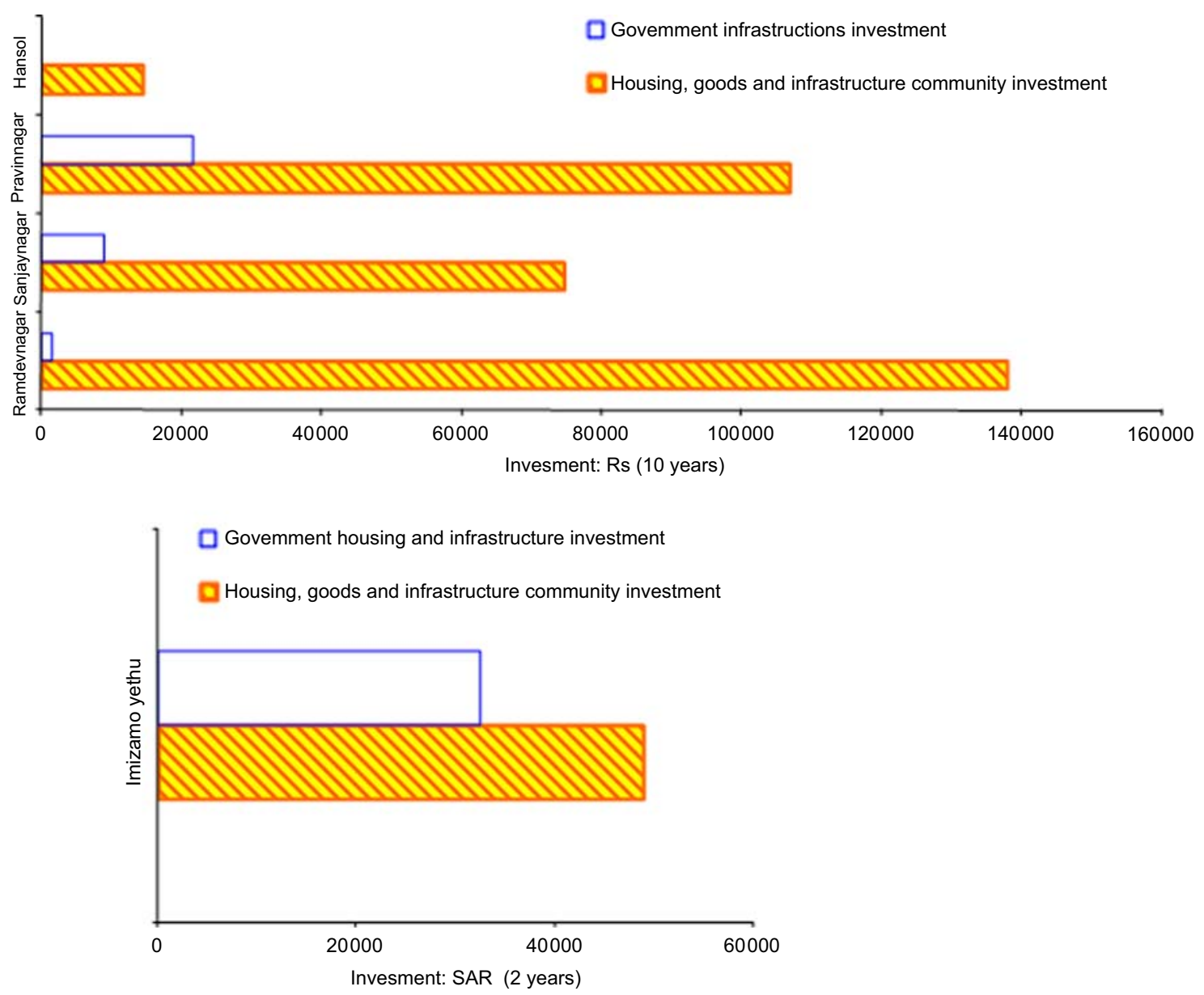

Figure 15. Investment in housing and goods (source: Parikh

(2008))

form of a monthly loan. This goes against the notion of the 'poor' not able and willing to invest in infrastructure and housing. The policy implications of this finding are significant as a majority of the housing projects are based on the assumptions that slum communities cannot contribute. In South Africa, while the government has made a commitment to provide housing to low-income communities, there is a gap between the housing need and resources/land availability. Even in India, the slum population constitutes between 20 and 50\% of the urban population in cities and filling this gap is going to be a challenge. Integrated infrastructure, if provided appropriately, can generate community investments in housing stock and this could potentially be a more effective method of solving the housing problem.

In all the non-serviced slums and for the hypothetical nonserviced scenario in serviced slums, respondents gave top priority to investments in water and sanitation infrastructure in preference to housing, health, education and employment.
This is reinforced by the reversal in priorities from infrastructure to other sectors once the physical development work was done in the serviced slums. This is in contrast to the perceptions in most development agencies that, while water and sanitation are important, priority investments should be made in other sectors such as health, education and governance.

The 'assumed' poor have found an entire network for funding that remains largely unrecognised in the developmental strategies. The market-based approach for funding projects in the field of poverty alleviation opens up the possibility of innovative partnerships between private companies, communities and governments. The advantage of a financial partnership is that each contributor gets a high return (multiplier) for a small investment and there is a sense of ownership. This also means that governments can potentially invest effective small amounts in integrated infrastructure for a large population to initiate community investments in housing stock. 

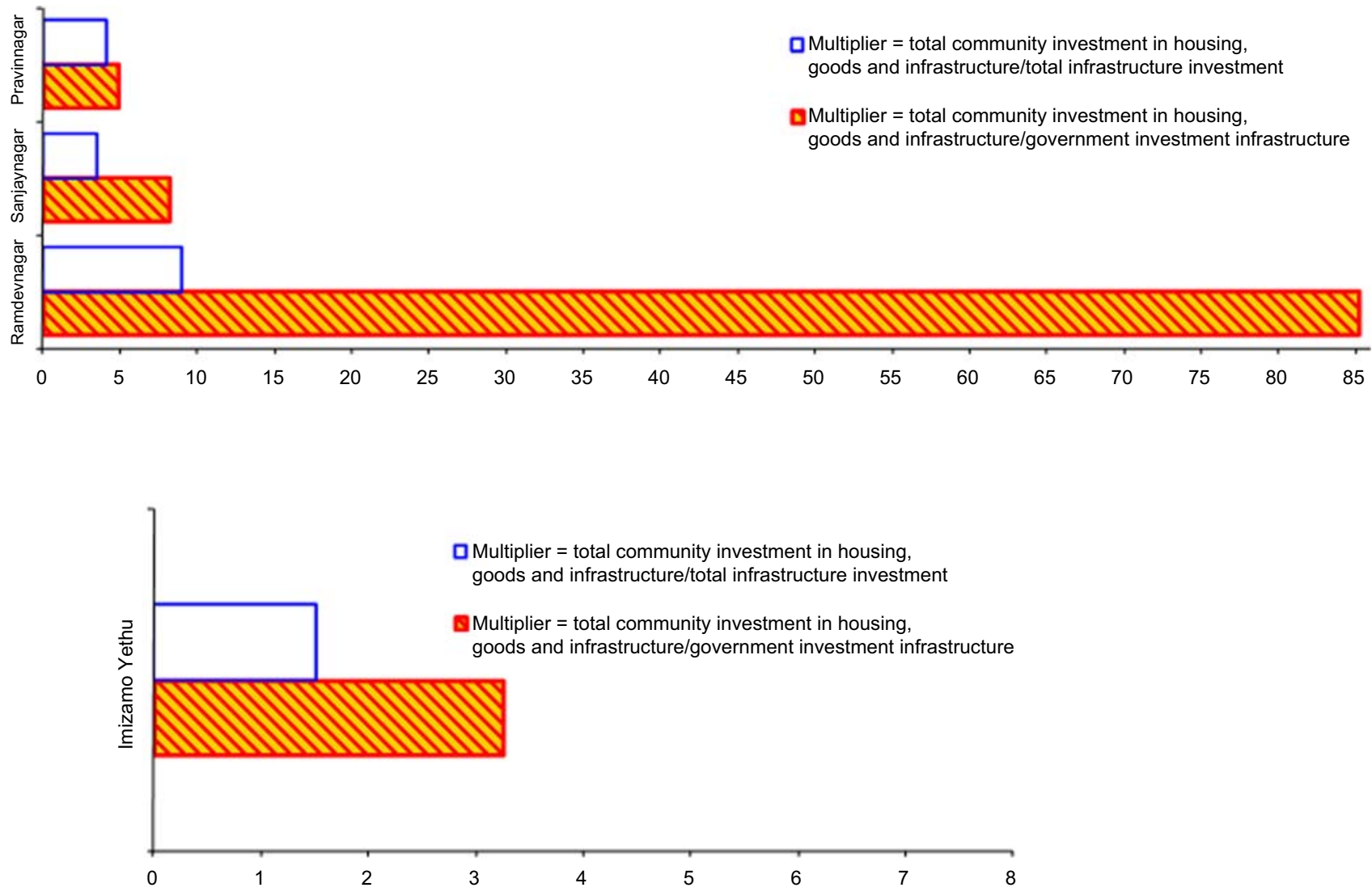

Figure 16. Multiplier (source: Parikh (2008))

\section{REFERENCES}

AMC (Ahmedabad Municipal Corporation) (2005) Slum Networking Programme: A Partnership Programme of Infrastructure and Social Development in Slums of Ahmedabad City. Submitted to HSMI (Human Settlement Management Institute).

Cape Gateway (2008) Information on Health Subsidies in Cape Town. See http://www.capegateway.gov.za/eng/pubs/ public_info/G/87726/3 (accessed 12/04/2008)

Census (2001) Census of Indian data accessed from the software package Devinfo provided by UNICEF India.

Dasgupta P (1993) An Inquiry into Well-Being and Destitution. Clarendon Press, Oxford, UK.

Diacon D (1997) Slum Networking 'An Innovative Approach to Urban Development'. Building and Social Housing Foundation, UK.

Joshi R (2002) Integrated slum development: Case of PravinnagarGuptanagar. In Poverty and Vulnerability in a Globalising Metropolis Ahmedabad (Kundu A and Mahadevia D (eds)). Manak Publications, India, pp. 268-308.

Parikh H (1999) Slum Networking: An Alternate Way to Reach the Urban Poor, Using Slums to Save Cities.
Himanshu Parikh Consulting Engineers, Ahmedabad, India.

Parikh P (2005) An Innovative Approach to Physical Infrastructure as a Means to Overcoming Poverty in Developing Countries. MPhil thesis, Cambridge University, Cambridge, UK.

Parikh P (2008) Impact of Integrated Water and Environmental Sanitation Infrastructure on Poverty Alleviation. $\mathrm{PhD}$ thesis, Cambridge University, Cambridge, UK.

Parikh P and McRobie A (2009) Engineering as a tool for improving human habitat. International Journal of Management and Decision Making 10(3/4): 270-281.

Payne G (2001) Land rights: Innovation in land tenure for the urban poor. Proceedings of the UNCHS International Workshop on Securing Land for the Urban Poor, Tokyo. See https://www.gpa.org.uk (accessed 14/02/2008).

Sandhu R (1998) The infrastructure development in slums: An experience of a medium size city in Punjab. In Slum Upgradation: Emerging Issue and Policy Implications (Sehgal R (ed.)). Bookwell Publications, Delhi, India, Ch. 10.

Sethuramalingam V (1998) National shelter demonstration project at Ennore, Madras: An experimentation of 
community participation in shelter for shelterless. In Slum Upgradation: Emerging Issue and Policy Implications (Sehgal R (ed.)). Bookwell Publications, Delhi, India, Ch. 14.

SEWA (Self Employed Women's Association) (2002) Parivartan and its Impact: A Partnership Programme of Infrastructure Development in Slums of Ahmedabad City. SEWA, Ahmedabad, India.

De Soto H (2000) The Mystery of Capital: Why Capitalism Triumphs in the West and Fails Everywhere Else. Basic Books, USA.

Tripathi D (1998) Alliance for Change: Slum Upgrading Experiment in Ahmedabad. Tata McGraw Hill, Ahmedabad, India.

UNICEF (United Nations Children's Fund) (1999) Urban Initiative - Slum Networking Strategy: A Community Based Water and Environmental Sanitation Demonstration Project in Ramdevnagar, Baroda. Gandhinagar.

UTV (2005) The Week the Irish Came to Town. Garry Kelly visits Imizamo Yethu, Cape Town. UTV Press Office, December 2005, see http://u.tv/corpinfo/releases/docs/424. doc (accessed 23/03/2008).

WB (World Bank) (2004) World Development Report: Making Services Work for Poor People. Oxford University Press, New York.

WHO/UNICEF (World Health Organisation/United Nations Children's Fund) (2004) Meeting the MDG Drinking Water and Sanitation Target: A Mid Term Assessment of Progress. See http://www.unicef.org/publications/files/ who_unicef_watsan_midterm_rev.pdf (accessed 23/05/ 2012).

\section{WHAT DO YOU THINK?}

To discuss this paper, please email up to 500 words to the editor at journals@ice.org.uk. Your contribution will be forwarded to the author(s) for a reply and, if considered appropriate by the editorial panel, will be published as discussion in a future issue of the journal.

Proceedings journals rely entirely on contributions sent in by civil engineering professionals, academics and students. Papers should be 2000-5000 words long (briefing papers should be 1000-2000 words long), with adequate illustrations and references. You can submit your paper online via www.icevirtuallibrary.com/content/journals, where you will also find detailed author guidelines. 